\title{
Analisis Penyebab Pernikahan Usia Dini Di Kecamatan Pleret Kabupaten Bantul
}

\author{
M. Sulkhan Zainuri ${ }^{1}$, Hartoyo ${ }^{2}$, Muhajir ${ }^{3}$, M.N.K Al Amin ${ }^{4}$, Andri Irawan ${ }^{5^{*}}$, Iin Sunny \\ Atmadja $^{6}$ \\ ${ }^{1}$ STEI Yogyakarta ${ }^{2}$ KUA Kecamatan Pleret Kabupaten Bantul, ${ }^{3}$ STAI An-Nawawi \\ Purworejo, ${ }^{4,5,6}$ Universitas Cokroaminoto Yogyakarta \\ *Penulis Koresponden, email: andrie.ir@gmail.com
}

\begin{abstract}
Abstrak
Di pedesaan sering kali terjadi pernikahan usia dini yang telah dibatasi dalam perundangan perkawinan Indonesia. Banyak penyebab terjadinya mereka terpaksa melakukannya. Di kecamatan Pleret ada kecenderungan peningkatan warga yang menikah usia dini. Penelitian studi kasus secara kualitatif kemudian dilakukan untuk mendeksripsikan secara alamiah tentang penyebab pelaksanaan praktek pernikahan di bawah usia terjadi di lokasi penelitian. Pendekatan sosio yuridis dilakukan terhadap data yang telah dikumpulkan melalui observasi, dokumentasi dan wawancara mendalam dengan informan yang dipilih secara purpossive sample. Sebagian besar melakukan pernikahan usia dini disebabkan karena faktor ekonomi dan pendidikan. Penyebab intervensi atau perananan orang tua maupun adat budaya tidak bepengaruh sebesar dua factor pertama. Batasan usia perkawinan dalam perundangan belum difahami secara tegas dan ketat bagi kepentingan masa depan mereka sendiri sehingga masih memberikan peluang bagi praktek perkawinan usia dini.
\end{abstract}

Kata kunci: pedesaan, pernikahan usia dini, penyebab

\begin{abstract}
Many rural residents are still married under the age specified in the Indonesian marriage law. There are many reasons why they are forced to do it in Pleret sub-district there is an increasing trend of people who marry at an early age. A qualitative case study research was then conducted to naturally describe the causes of the practice of underage marriage in the research location. The socio-juridical approach was carried out on the data that had been collected through observation, documentation and in-depth interviews with informants selected by purpossive sample. Most of them do early marriage because of economic and educational factors. The causes of intervention or the role of parents or cultural customs do not have as much influence as the first two factors. The age limit of marriage in the legislation has not been clearly and strictly understood for their own future interests so that it still provides opportunities for the practice of early marriage.
\end{abstract}

Keywords: rural, early marriage, causes

This is an open access article under the (1-BY-SA license @) (1) ( ) 


\section{Latar Belakang Masalah}

Pernikahan yang merupakan cikal bakal terciptanya keluarga. Perannya sebagai tahap pertama dalam pembentukannya dengan tujuan untuk mewujudkan keluarga yang bahagia, damai, sejahtera lahir dan batin (Hadikusuma 2016:170). Di samping itu pernikahan merupakan ikatan yang sakral bernilai ibadah (Ramulyo 2004:1).

Dalam pencapaian tujuannya memerlukan pengaturan, namun bukan sebagai pengekangan terhadap yang berkehendak. Gunanya untuk menyadarkan bahwa pernikahan termasuk dalam masalah ibadah dan sosial sekaligus seperti yang terungkap dalam Al Qur'an Surat Ar Rum (30): 21 (Departemen Agama RI 2010).

Pernikahan demikian memiliki beberapa fungsi. Antara lain (Shihab 2018:13-15); fungsi keagamaan yang kuat sehingga dapat diajarkan dan diwarisksan kepada generasi selanjutnya secara berkelanjutan. Fungsi Sosial Budaya yang berketahanan berkebangsaan dan berkebudayaan yang pencapaiannya hanya bisa melalui pelestarian ikatan keluarga. Fungsi cinta kasih bagi sesama. Hal itu bisa terjalin karena komunikasi baik dan interns terjalin dalam berkeluarga (Amin 2018; Nafi dan Al-Amin 2018). Fungsi reproduksi berupa keturunan yang baik berdasar keturunan yang pasti sebagai kemaslahatan daruri guna menghindarkan generasi yang syubhat dan tersamar.

Fungsi Pendidikan dimana orang tua membimbing anak untuk memahami dan mengamalkan agama dan ilmu pengetahuan dalam menghadapi segala tantangan masa depan secara fisik dan psikis. Fungsi Ekonomi dimana kerjasama suami istri harus terus dikembangkan memenuhi kebutuhan hidup keluarga. Fungsi pembinaan lingkungan karena keluarga dapat memberi pengaruh terhadap lingkungannya kemampuan dalam penempat diri yang sesuai dengan tatanan kemasyarakatan di sekitar. (Shihab 2018).

Untuk menjaga kerukunan dalam rumah tangga yang sesuai dengan fungsi dan tujuan perundangan diperlukan sebuah kedewasaan dalam berpikir dan bertindak sebelum dan selama perkawinan. Para pihak yang hendak 
nikah harus memiliki kesadaran tentang kompleksitas dari kehidupan berkeluarga. Akibat hukum dari perkawinan itu memunculkan hak dan kewajiban yang wajib dilaksanakan di antara keduanya, bahkan bila pernikahan terputus akibat salah satu meninggal, atau dibatalkan. Kesetaraan dan keseimbangan dalam istilah kufuk yang diperlukan dalam perkawinan Islam menjadi pandangan yang patut dipertimbangkan (Bashori dan Sembodo 2018).

Pertimbangan kedewasaan bisa ditinjau dari sisi usia. Munir (2003) menegaskan, batas umur perkawinan berkaitan pola kesiapan dalam mendirikan kehidupan berumahtangga. Perkawinan yang terjadi antara mereka yang sudah siap dan belum siap secara usia bisa menghasilkan situasi kondisi kehidupan berumah tangga yang berbeda.

Dalam Islam, Shihab (2018:109) menuturkan batasan umur pernikahan itu sesuai dengan kategori balig bagi lelaki dan perempuan yang akan menikah. Dalam hokum Indonesia, pasal 7 Undang-Undang Nomor 1 Tahun 1974 Tentang Perkawinan (1974), telah diatur calon suami sekurangkurangnya berumur 19 tahun dan calon istri sekurang-kurangnya berumur 16 tahun". Ketentuan perundangan tersebut dikuatkan dalam KHI pasal 15 ayat (1) (Irawan 2011; RI 1991).

Wafiq \& Santoso (2017) telah mendeskripsikan bagaimana kesungguhan aparat Kantor Urusan Agama di Bantul guna mensosialisasikan batasan usia pernikahan dan memperketat implementasi hokum pernikahan usia dini di wilayah wewenangnya. Bahkan ada usulan untuk ditetapkan kebijakan kriminalisasi, baik secara pidana maupun non-pidana agar pernikahan di bawah usia yang ditetapkan perundangan untuk perlindungan bagi kesejahteraan anak (Isma, Din, dan Mujibussalim 2017). Secara budaya, sebuah desa di Bali telah menjadikan perangkat budaya perarem atau," berisi prosedur teknis yang menjadi kesepakatan para prajuru adat dalam musyawarah desa yang mengatur tata cara beribadah, tata krama pergaulan warga, dan tata ruang (Tri Hita Karana) sebagai sarana mengurangi pernikahan usia dini di salah desanya. Kesepakatan ini dapat tertulis atau 
tidak bila tidak bertentangan dengan ketentuan yang tertuang dalam awig-awig desa atau peraturan umum,"(Suka et al. 2013).

Namun pernikahan dini sekarang menjadi suatu fenomena yang menarik perhatian banyak pihak. Namun pernikahan dini sebagai hal yang biasa dan wajar terjadi dalam kehidupan berkeluarga masih banyak muncul ke permukaan. Apalagi hukum pernikahan di bawah umur memang dibolehkan dengan pembatasan. Bentuknya dispensasi pengecualian untuk melakukan perkawinan dari peradilan agama bagi yang muslim dari peradilan agama. Izin dispensasi dari peradilan agama juga dikenakan pada pernikahan poligami (Asmorohadi 2018)

Dalam agama Islam, untuk menghadapi budaya global yang permisif, pernikahan usia dini pun dijadikan sarana penting. Munir (2003) memaparkan pernikahan usia dini adalah alternatif penting menghindari pergaulan tanpa batas dalam masyarakat. Hal yang sama diutarakan oleh Adhim (2006) dimana sisi negativenya bisa ditannguhkan terlebih dahulu. Keduanya sama-sama juga melihat penyebab utama dari pergaulan bebas yang menyebabkan pernikahan dini adalah dari keluasan dampak multi media berpaham lain yang dominan hingga pelosok pedesaan.

Suka et al. (2013) menceritakan adat budaya nikah massal di Desa Pengotan di Bali telah mendorong terjadinya perkawinan antar mudamudi yang masih remaja dalam rentang usia 14-18 tahun. Damayati (2016) memberikan kesimpulan dalam penelitiannya bahwa hamil sebelum nikah, tingkat pendidikan pelaku, dan tingkat ekonomi keluarga pelaku dan hokum memberikan pengaruh yang besar dibanding factor internal pelaku atau orang tuanya ataupun budaya adat lokal. Penelitian Puspitasari (2006) mengurainya dengan melihat pengaruh saat mengasuh anak pola asuh keluarga di sebuah desa di Tasikmalaya. Data kualitatif terkumpul wawancara dan observasi. Untuk menemukan faktor penyebab terjadinya perkawinan di usia dini di wilayah itu adalah faktor ekonomi, faktor pendidikan, faktor orang tua, faktor diri sendiri, dan faktor adat setempat. Ia tidak membandingkan antar faktor seperti yang dilakukan oleh Damayanti. 
Zulkifli (2011) juga melakukan penelitian mengenai dampak Sosial pernikahan usia dini yang berada di Desa Gunung Sindur- Bogor. Penelitian ini mengungkapkan bahwa sangat terbatasnya pengetahuan masyarakat pernikahan usia dini antara lain disebabkan karena tingkat pendidikan masyarakat sangat rendah. Faktor lainnya adalah hamil di luar nikah dan takut maksiat. Dari semua itu, ekonomi adalah sebagai faktor pendorong yang paling dominan. Di Pangkep Sulawesi, selain factor ekonomi, pendidikan, orang tua dan gender, ada adat budaya yang mempengaruhi yaitu paham leluhur yang mangharuskan anaknya menikah ketika sudah ada tiga pemudah datang melamar maka yang ketiga harus diterima karena takut tidak akan ada lagi yang datang dan ini memang terbukti bahwa ketika sudah cukup tiga laki-laki datang melamar maka sulit ada laki-laki yang keempat untuk datang melamar lagi (Zulfadli, Ridwan, dan Patimah 2016). Hal Yang sama ditemukan di daerah sebuah desa Kabupaten Sidoarjo. Masyarakat telah terbiasa dengan perkawinan di bawah usia 20 tahun bahkan akibat hamil di luar nikah. Mawardi (2012) menemukan sisi internal pelaku dan orang tua yang menimnulkan pergaulan bebas selain kemudahan akses pornografi. Orang tua focus kepada kerja sehingga kurang perhatian dari orangtua terhadap anak karena orang tua sibuk bekerja, atau berstatus orang tua. Pendidikan di keduanya juga minim dari pengetahuan agama dan pengamalan sehingga lingkungan kurang mendukung. Mawardi melanjutkan,"Pada orangtua pihak perempuan juga mendukung anaknya untuk melakukan apa saja untuk memenuhi permintaan pacarnya karena takut tidak jadi dinikah, sementara laki-laki tergolong sudah mapan dalam ekonomi dan orangtua merasa ada kecocokan sehingga berharap anaknya dapat menikah dengan pacarnya. Sebaliknya karena orangtua tidak setuju pihak laki-laki sengaja menghamili pacarnya agar bisa menikah karena saling mencintai." (Mawardi 2016)

Sebagian warga desa di kecamatan Pleret Kabupaten Bantul mengalami penikahan usia dini. Diantaranya ada yang menikah tidak melalui saluran kelembagaan KUA, tetapi mencukupkan dengan pengakuan agama dengan menghadap tokoh atau pemuka agama setempat. Sementara 
Pemerintah Daerah DIY sedang gencar-gencarnya melakukan upaya-upaya hokum bagi perlindungan wanita bahkan bagi para difabel (Atmaja dan Irawan 2018; Irawan 2017). Data Pernikahan Tahun 2009, 2010 dan 2011 telah menunjukkan bahwa pernikahan di bawah umur telah terjadi lebih dari 10 kali setiap tahun (KUA 2012).

\section{Metode Penelitian}

Penelitian empiris ini dimaksudkan untuk dapat mendeksripsikan secara alamiah tentang alasan pelaksanaan praktek pernikahan di bawah usia terjadi di Desa Pleret Kabupaten Bantul dengan terjun langsung di lokasi penelitian. Deskripsi kemudian dianalisis secara kualitatif sesuai dengan karakter data yang dikumpulkan. Tekanannya pada identifikasi terhadap faktor-faktor yang mempengaruhinya. Pengamatan menjadi penting karena ingin mengumpulkan data tentang praktek pernikahan usia dini yang sangat memudahkan dengan cara pengamatan dan pencatatan saat pelaksanaan. Dokumentasi juga mendukung terutama dalam seleksi data pernikahan usia dini dari yang lain selain landasan hokum ataupun dokumen prosedur dan bentuk dokumen lainnya yang mendukung. Proses pengumpulan kedua itu diutamakan pada data pernikahan yang ada di KUA dengan prioritas pernikahan usia dini yang penting untuk dielaborasi lebih lanjut melalui wawancara. Untuk wawancara, informan dipilih dengan tujuan tertentu karena ingin mengetahui pandangan mereka yang telah melakukan pernikahan tersebut setelah berjalan beberapa tahun, karena perjalanan waktu akan memberikan keluasan wawasan dan pengalaman yang patut dijadikan sumber data. Informan kemudian ditentukan berdasar data yang ada di KUA Desa Pleret pada tahun 2010 dan masih berdomisili di Pleret ketika penelitian berlangsung. Data kemudian dianalisis dengan pendekatan sosio yuridis, yaitu pendekatan dengan melihat aspek gejala social masyarakat yang ada di wilayah Desa Pleret, pada peristiwa pelaksanaan pernikahan usia dini dan akibatnya.

\section{Hasil dan Pembahasan}

Peristiwa Pencatatan Pernikahan Kurang Umur, di KUA Pleret 
Kabupaten Bantul Daerah Istimewa Yogyakarta tahun 2010 terjadi sebanyak 15 kali.

Tabel 1

Pencatatan Nikah Kurang Umur

\begin{tabular}{|c|c|c|c|c|c|}
\hline \multirow{2}{*}{ No. } & \multirow{2}{*}{ No. Akta Nikah } & \multirow{2}{*}{ Suami } & \multirow{2}{*}{ Istri } & \multicolumn{2}{|c|}{ Umur } \\
\hline & & & & Suami & Istri \\
\hline 1. & $04 / 04 / \mathrm{I} / 2010$ & NY & Rw & 17 & 16 \\
\hline 2. & 19/19/I/2010 & $\mathrm{AFN}$ & VW & 17 & 17 \\
\hline 3. & $23 / 04 / \mathrm{II} / 2010$ & SR & $\mathrm{DM}$ & 17 & 16 \\
\hline 4. & $35 / 06 / \mathrm{II} / 2010$ & $\mathrm{Zd}$ & $\mathrm{NN}$ & 17 & 17 \\
\hline 5. & $48 / 05 / \mathrm{III} / 2010$ & $\mathrm{DP}$ & ATH & 17 & 17 \\
\hline 6. & 49/06/III/2010 & Gy & $\mathrm{Mj}$ & 17 & 17 \\
\hline 7. & 51/08/III/2010 & Hy & $\mathrm{SH}$ & 17 & 16 \\
\hline 8. & $55 / 12 / \mathrm{III} / 2010$ & $\mathrm{MH}$ & HS & 17 & 16 \\
\hline 9. & $71 / 28 / \mathrm{III} / 2010$ & $\mathrm{AS}$ & $\mathrm{FF}$ & 17 & 16 \\
\hline 10. & $72 / 29 / \mathrm{III} / 2010$ & JS & TW & 17 & 17 \\
\hline 11. & $86 / 43 /$ III/2010 & AR & $\mathrm{Rm}$ & 17 & 16 \\
\hline 12. & 102/04/IV/2010 & $\mathrm{AF}$ & $\mathrm{LF}$ & 17 & 17 \\
\hline 13. & $110 / 22 / \mathrm{IV} / 2010$ & $\mathrm{Ch}$ & $\mathrm{YN}$ & 17 & 17 \\
\hline 14. & $111 / 23 / \mathrm{IV} / 2010$ & HS & RK & 17 & 16 \\
\hline 15. & $119 / 06 / \mathrm{V} / 2010$ & AWS & $\mathrm{RR}$ & 17 & 17 \\
\hline
\end{tabular}

Sumber : Data dari Pemeriksaan Nikah KUA Pleret

Tabel tersebut di atas dapat memberikan informasi mengenai kategori umur saat melangsungkan pernikahan kurang dari 18 Tahun dan orang tua perlu memberikan Izin untuk dapat melaksanakan pernikahan, sebagai syarat kelengkapan (N5) dan Dispensasi Pengadilan Agama setempat apabila kedua calon pasangan suami dan istri di bawah 16 tahun.

Tabel 2

Tingkat Pendidikan Responden

\begin{tabular}{|c|l|c|c|}
\hline No & Variasi Pendidikan & Jumlah & $\mathbf{\%}$ \\
\hline 1 & SD / yang sederajat & 7 & 46 \\
2 & SLTP / yang sederajat & 4 & 26 \\
3 & SLTA / yang sederajat & 3 & 20 \\
4 & Akademi / PT & - & 0 \\
5 & Tidak lulus SD & 1 & 0,6 \\
\hline \multicolumn{2}{|c|}{ Total } & $\mathbf{1 5}$ & \\
\hline
\end{tabular}

Sumber : Data dari Pemeriksaan Nikah KUA Pleret

Dari data di atas dapat diketahui tingkat pendidikan responden yang paling banyak di bangku SD atau sederajat sebanyak 7 (46\%) responden, dan diikuti SLTP atau yang sederajat sebanyak 4 (26\%) responden, dan Tingkat 
SLTA atau yang sederajat 3 (20\%) responden, dan tidak lulus SD sebanyak 1 ( 0,6\%) responden dan Akademi/PT sebanyak 0 (-\%).

Data ini menunjukkan semakin tinggi pendidikan semakin berkurang keinginan untuk melakukan pernikahan usia dini. Secara sosial, suami istri dari pernikahan usia dini yang tidak lulus SD di Desa Pleret juga semakin sedikit ditemui karena kebijakan wajib belajar secara nasional dari pemerintah memang memudahkan bagi masyarakat untuk menyelesaikan pendidikan SD. Ketika keluarga ingin melanjutkan anak sekolah selanjutnya yang mengharuskan biaya mandiri, maka kesulitan keuangan menjadi persoalan bagi kelanjutan pendidikan anaknya.

Rendahnya tingkat pendidikan maupun pengetahuan orang tua, anak dan masyarakat, menyebabkan adanya kecenderungan mengawinkan anaknya yang masih dibawah umur. Meski demikian, mereka sangat menghargai makna pernikahan, hal ini di buktikan dengan komitmen mereka menjalani kehidupan pernikahan di usia yang masih sangat muda. Kendala pemahaman mereka sangat kurang dan terbatas tentang kehidupan pernikahan dan keluarga, menyebakan mereka sesungguhnya belum mengerti apa arti pernikahan yang mereka lakukan, bahkan mereka tidak mengetahui bahwa ada Undang-undang perkawinan yang mengatur tentang batas-batas usia pernikahan. Mereka juga tidak menyadari bahwa dalam kehidupan suami istri sering terjadi perbedaan pendapat yang memerlukan kemantapan dan ketenangan jiwa untuk mengarunginya.

Hal itu bisa terlihat dari jumlah profesi yang mereka tekuni saat pendaftaran nikah.

Tabel 3

Pekerjaan Responden

\begin{tabular}{|l|l|c|r|}
\hline No. & \multicolumn{1}{|c|}{ Jenis Pekerjaan } & Jumlah & \multicolumn{1}{c|}{$\%$} \\
\hline 1. & Tani & 2 & 13,7 \\
2. & Pegawai / Karyawan / & 5 & 34,3 \\
3. & Buruh & 4 & 26 \\
4. & Dagang / Wiraswasta & - & 0 \\
5. & TNI / POLRI & 4 & 26 \\
\hline \multicolumn{2}{|c|}{ TOTAL } & $\mathbf{1 5}$ & $\mathbf{1 0 0}$ \\
\hline
\end{tabular}

Sumber : Data dari Pemeriksaan Nikah KUA Pleret 
Dari data di atas diketahui frekuensi terbanyak sebagai karyawan atau buruh terdapat $5(33,3 \%)$ responden, diikuti wiraswata terdapat 4 (26\%) responden, setelah itu baru diikuti tidak mempunyai pekerjaan tetap sebesar 4 (26\%) responden. Dan seterusnya Tani sebanyak 2 (13\%) dan terakhir TNI / POLRI sebanyak 0 ( $0 \%$ ).

Kelompok karyawan/buruh hanya memiliki pendapatan bulanan dalam kisaran Rp 1.000.000 - Rp 1.500 .000 yang menjadi banyak pelaku pernikahan usia dini adalah mereka yang bergerak di sector swasta nonformal yang tidak membutuhkan persyaratan pendidikan tinggi dan keahlian tertentu. Mereka tidak memiliki daya tawar terhadap kemampuan diri sendiri dalam berkerja selain kekuatan fisik yang seharusnya tidak demikian dalam proses bekerja. Secara umum juga bisa disimpulkan bahwa mereka tidak banyak yang berkerja di sector public yang masih ketat dalam peraturan perkawinan dibanding pekerjaan swasta. Karena itu dari pelaku dari TNI dan Polri masih sangat sedikit, selain bahwa dari sisa usia tidak memungkinkan apabila suami istri dalam usia yang setara.

Motif ekonomi juga muncul ketika pelaku nikah usia dini memutuskan menikah dari inisiatif sendiri. Tujuannya ingin meringankan beban ekonomi orang tuanya dengan cara menikah pada usia dini. Adapula yang menikah dalam usia dini karena faktor kesulitan ekonomi dan berharap dengan melakukan pernikahan lebih cepat akan dapat meringankan beban orang tuanya.

Selain factor ekonomi dan pendidikan, orang tua juga menjadi penentu dalam pernikahan usia dini. Orang tua khawatir kena aib karena anak perempuannya berpacaran dengan laki-laki yang sangat lengket sehingga segera mengawinkan anaknya. Adapula faktor karena informan yang sudah hamil di luar nikah yang terpaksa harus dinikahkan untuk menghindari aib keluarga mereka. Penyebab terjadinya perkawinan di bawah umur, yaitu karena orang tua lebih memilih segera menikahkan anaknya. Walaupun masih dibawah umur daripada anak perempuannya terlanjur hamil duluan. Selain itu keharusan anak untuk menaati perintah orang tuanya yaitu 
menikah meskipun diusia dini untuk dapat membantu perekonomian keluarga mereka.

Faktor adat juga berperan terhadap orang tua atau pasangan memutuskan nikah di usia dini. Adat Jawa di Pleret masih kuat memandang keharusan perempuan untuk dilamar. orang tuanya takut anaknya dikatakan perawan tua sehingga segera dikawinkan. Kebanggaan tersendiri apabila anaknya yang berusia masih belia yang masih duduk dibangku SD sudah dilamar. Justru berbeda apabila seorang gadis belum juga dilamar hingga di usia matang maka akan menjadi kekhawatiran orang tua terhadap masa depan anaknya.

Tabel 4

Faktor-Faktor Penyebab Pernikahan Usia Dini

\begin{tabular}{|c|l|c|c|c|c|c|c|}
\hline \multirow{2}{*}{ No. } & \multirow{2}{*}{ Penyebab } & \multicolumn{3}{|c|}{ Jawaban } & \multicolumn{3}{c|}{$\%$} \\
\cline { 3 - 8 } & & A & B & C & A & B & C \\
\hline 1. & Faktor Ekonomi & 6 & 6 & 3 & 40 & 40 & 20 \\
\hline 2. & Faktor Pendidikan & 7 & 7 & 1 & 46 & 46 & 0,6 \\
\hline 3. & Faktor Orang tua & 4 & 6 & 5 & 26 & 40 & 33,3 \\
\hline 4. & Faktor Media Masa & - & - & - & 0 & 0 & 0 \\
\hline 5. & Faktor Adat & 5 & 5 & 5 & 33,3 & 3,3 & 33,3 \\
\hline
\end{tabular}

Sumber : Data dari Pemeriksaan Nikah KUA Pleret.

Dari data di atas dapat diketahui faktor Pernikahan usia dini disebabkan oleh kelima faktor tersebut di atas, dimana responden mengaku sebanyak $15(100 \%)$ responden menyadari kelima faktor tersebut berkaitan penyebab pernikahan di usia dini, Faktor ekonomi akan mempengaruhi pendidikan tidak dapat menyelesaikan jenjang SMU sederajat. Karena alasan orang tua tidak mampu untuk membiayai Pendidikan anaknya melanjutkan sekolah. Akhirnya anak diizinkan menikah dengan calon pasangannya, walau umur menurut ketentuan belum di perbolehkan, mengurangi tanggung jawab orang tua dalam membiayai hidup.

Fakta yang ditemukan ini seimbang dengan yang diyatakan oleh Damayati (Damayati 2016) dan Zulkifli (Ahmad 2011). Ekonomi dan pendidikan menjadi dua factor penentu dalam pernikahan usia dini setelah diolah dengan statistik regresi. Meski demikian hamil di luar nikah juga turut 
andil yang besar juga di Desa Pleret meski tidak dimunculkan dalam data yang tersedia di KUA. Hal itu bisa dilihat dari para pelaku nikah di usia dini dengan dispensasi pengadilan dalam data pemeriksaan KUA hanya terdiri dari dua pasangan pada tahun 2010. Hal itu juga dimungkinkan seperti yang diutarakan oleh Mawardi (Mawardi 2016) bahwa budaya pornografi telah menyebabkan hubungan seksual pra-nikah sebagai sebuah kelaziman. Akses dari budaya tabu itu sebenarnya melalui teknologi multi media sehingga seharusnya juga menjadi pertimbangan dalam pilihan responden dan informan. Pandangan belum memikirkan sedemikian jauh sehingga mengabaikan dalam pertimbangan sebagai factor disbanding yang lain.

Faktor orang tua di urutan selanjutnya setelah dua factor ekonomi dan pendidikan. Hal ini memang berlawanan dengan penelitian Mawardi (Mawardi 2012) di Sidoarjo yang memandang anak dan orang tua adalh penentu terjadi pernikahan usia dini, namun memiliki kesamaan dengan Damayanti (2016) dan Puspitasari (2006). Dalam pandangan keduanya, otoritas memang sangat tinggi tetapi tidak menjadi pengambil keputusan dalam pernikahan usia dini. Adatpun demikian, banyak peneliti tidak begitu berperan lebih dari dua factor yang tersebut di atas (Ahmad 2011; Damayati 2016; Fitra Puspitasari 2006; Mawardi 2012), meski Suka dkk. memandang berbeda karena agama dan budaya yang masih kuat di kehidupan pedesaan di Bali.(Suka et al. 2013).

Sebagai perimbangan juga bahwa benang merah yang muncul dalam pernikahan usia dini yang terjadi dalam pola pengambilan keputusannya. Perimbangan yang diutamakan belum memberikan factor orientasi masa depan keluarga dalam cakupan yang lebih besar dari pertimbangan sesaat. Sementara selama perjalanan berkelurga, pernikahan dini bisa berdampak negatif selama kehidupan berjalan. Secara Psikologis, Kondisi mental yang cenderung masih labil dikhawatirkan akan memberikan dampak negatif bagi psikologi sang anak, apalagi bila belum memiliki pengetahuan mendalam tentang perkawinan dan kehidupan berumah tangga, termasuk semua hak dan kewajiban yang akan dijalani. Pernikahan muda membahayakan bagi kesehatan kandungan.(Alfina, Akhyar, dan Matnuh 2016). Dampak hokum 
dari perkawinan, pembatalan maupun perceraian (Muthmainnah dan Santoso 2019; Nafi dan Al-Amin 2018; Zainuri 2019) juga belum menjadi pertimbangan.

\section{A. Penutup}

Pernikahan usia dini yang terjadi di Pleret Kabupaten Bantul dipengaruhi secara tidak langsung dengan keberadaan struktur sosial budaya karena ketentutuan minimal umur daslam perkawinan belum difahami secara jelas dan pasti sehingga para remaja dan orang tuanya berkesempatan untuk melakukan perkawinan usia dini. Penduduk terpaksa melakukan perkawinan usia dini banyak disebabkan dari faktor ekonomi dan pendidikan. Meski lainnya, seperti perananan orang tua atau adat budaya, bepengaruh tetapi tidak sebesar dua factor pertama. Sebagai saran, Pemerintah dan lembaga privat bisa memajukan pendidikan di wilayahnya. Kelengkapan sarana dan prasarana seperti sekolah atau pendidikan pra pernikahan yang bisa diakses oleh semua pihak. Ini juga memudahkan pengawasan terhadap anak dan remaja sehingga tidak terjadi kekhawatiran orang tua terhadap anak akab berbuat di luar batas menyebabkan pernikahan usia dini.

\section{Daftar Pustaka}

Adhim, Muhammad Fauzil. 2002. Indahnya Menikah Usia Muda. Jakarta: Gema Insani.

Ahmad, Zulkifli. 2011. "Dampak Sosial Pernikahan Usia Dini Studi Kasus di Desa Gunung Sindur-Bogor." UIN Syarif Hidayatullah.

Alfina, Refqi, Zainul Akhyar, dan Harpani Matnuh. 2016. "Implikasi Psikologis Pernikahan Usia Dini Studi Kasus Di Kelurahan Karang Taruna Kecamatan Pelaihari Kabupaten Tanah Laut." Jurnal Pendidikan Kewarganegaraan 6(2):1021-32.

Amin, M. N. K. Al. 2018. "Komunikasi Sebagai Upaya Untuk Membangun Ketahanan Keluarga Dalam Kajian Teori Nilai Etik." Al-Ahwal: Jurnal Hukum Keluarga Islam 11(1):79-90.

Asmorohadi. 2018. "Pernikahan Poligami Di Wilayah Administrasi Kantor Urusan Agama Kecamatan Playen Tahun 2012-2015." Ulumuddin: Jurnal Ilmu-ilmu Keislaman 8(2):79-97.

Atmaja, Iin Suny, dan Andrie Irawan. 2018. "Peran Komite Perlindungan dan Pemenuhan Hak-Hak Penyandang Disabilitas Daerah Istimewa Yogyakarta dalam Perlindungan Hukum bagi Perempuan Disabilitas Korban Kekerasan." UIR Law Review 2(2):331-46. doi: 10.25299/uirlrev.2018.vol2(02).1321.

Bashori, Hasan, dan Cipto Sembodo. 2018. "Relevansi Fatwa Mazhab Syafi'i 
Tentang Kufu dalam Nikah Terhadap Kompilasi Hukum Islam (KHI)." Ulumuddin: Jurnal Ilmu-ilmu Keislaman 8(2):99-144.

Damayati, Nina. 2016. "Faktor-Faktor Yang Mempengaruhi Pernikahan Usia Dini Di Kecamatan Sungai Keruh Kabupaten Musi Banyuasin." JURNAL SWARNABHUMI: Jurnal Geografi dan Pembelajaran Geografi 1(1):72-79. doi: 10.31851/SWARNABHUMI.V1I1.819.

Departemen Agama RI. 2010. Al-Qur'an dan Terjemahan. Bandung: CV Diponegoro.

Fitra Puspitasari. 2006. "Perkawinan Usia Muda: Faktor-Faktor Pendorong Dan Dampaknya Terhadap Pola Asuh Keluarga ( Studi Kasus Di Desa Mandalagiri Kecamatan Leuwisari Kabupaten Tasikmalaya )." Unnes Semarang.

Hadikusuma, Hilman. 2016. Hukum Perkawinan Indonesia Menurut Perundangan, Hukum Adat, Hukum Agama. Bandung: Refika Aditama.

Irawan, Andrie. 2011. "Harmonisasi Hukum Nasional dan Hukum Islam dalam Mencari Batasan Usia Minimal Menikah bagi Anak." Jurnal Hukum Respublica 10(2):247-60.

Irawan, Andrie. 2017. "Peranan Pemerintah Daerah Istimewa Yogyakarta Dalam Perlindungan Hukum Terhadap Perempuan Penyandang Disabilitas Korban Kekerasan." Jurnal Ilmiah Hukum De'Jure 2(2):202-17.

Isma, Eli Dani, Mohd. Din, dan Mujibussalim. 2017. "Kebijakan Kriminal Dalam Penanggulangan Perkawinan Di Bawah Umur." Dusturiyah: Jurnal Hukum Islam, Perundang-undangan dan Pranata Sosial 7(1). doi: 10.22373/dusturiyah.v7i1.2337.

KUA. 2012. Data Perkawinan Kantor Urusan Agama Kecamatan Pleret Kabupaten Bantul. Bantul.

Mawardi, Marmiati. 2012. "Problems of Under Age Marriage." Analisa 19(2):201. doi: 10.18784/analisa.v19i2.166.

Mawardi, Marmiati. 2016. "Keluarga Sakinah: Konsep \& Pola Pembinaan." International Journal Ihya' 'Ulum al-Din 18(2):253-67. doi: 10.21580/ihya.17.2.1739.

Munir, Abdul. 2003. Pernikahan Dini di Yogyakarta dan Perspektif Masarakat Dari tahun. 2001-2003 Dalam Perspektif Hukum Islam. Yogyakarta: LKIS.

Munir, Agus Syahrur. 2003. Kedewasaan Perkawinan Dalam Undang-Undang Perkawinan Indonesia. Bandung: Mizan.

Muthmainnah, Muthmainnah, dan F. Setiawan Santoso. 2019. "Akibat Hukum Harta Bersama Perkawinan Dalam Pewarisan Di Indonesia Analisis Komparatif Hukum Islam Dan Hukum Adat." Ulumuddin: Jurnal Ilmu-ilmu Keislaman 9(1):81-96.

Nafi, Ahmad Zuhri, dan M. Nur Kholis Al-Amin. 2018. "Perceraian Karena Intervensi Orang Tua terhadap Rumah Tangga Anak." Ulumuddin: Jurnal Ilmu-ilmu Keislaman 8(2):115-30.

Ramulyo, Muh Idris. 2004. Hukum Perkawinan Islam, analisis dari UU No.1/1974 dan KHI. Jakarta: Bumi Aksara.

RI. 1974. Undang-Undang RI Nomor 1 tahun 1974 tentang Perkawinan.

RI. 1991. Instruksi Presiden Nomor 1 Tahun 1991 Tentang Kompilasi Hukum Islam. 
Shihab, M. Quraish. 2018. Perempuan. Tangerang: Lentera hati.

Suka, I. Ginting, MuninjayaA A G, WiastiNi Made, DewiA A S Kartika, dan Ni Ketut Aryastami. 2013. "Pemberdayaan Perarem untuk Menurunkan Angka Hamil di Luar Nikah dan Kawin Usia Muda di Desa Pengotan Kabupaten Bangli." Buletin Penelitian Sistem Kesehatan 16(3). doi: 10.22435/bpsk.v16i3.

Wafiq, Ahmad, dan F. Setiawan Santoso. 2017. "Upaya Yuridis Dan Sosiologis Kantor Urusan Agama Dalam Pencegahan Pernikahan Usia Dini." Ulumuddin: Jurnal Ilmu-ilmu Keislaman 7(1):17-30.

Zainuri, Sulkhan. 2019. "Status Perkawinan Suami Istri Pasca Pembatalan Perkawinan Islam Di Indonesia." Ulumuddin: Jurnal Ilmu-ilmu Keislaman 9(1):34-48.

Zulfadli, Zulfadli, M. Saleh Ridwan, dan Patimah Patimah. 2016. "FaktorFaktor Terjadinya Pernikahan Usia Anak Di Kabupaten Pangkep." Jurnal Diskursus Islam 4(2):201-16. doi: 10.24252/JDI.V4I2.7305. 